MICHAL KOSMAN,

DOI : $10.14746 /$ rie.2015.9.19 PAWEŁ MALENDOWICZ

Uniwersytet im. Kazimierza Wielkiego w Bydgoszczy

\title{
Glos polskich i niemieckich nacjonalistów w debacie na temat integracji europejskiej
}

W Europie początku XXI wieku funkcjonują i aktywizują się ruchy społeczne, organizacje i partie polityczne sprzeciwiające się procesowi integracji europejskiej. Wśród nich są ruchy i partie reprezentujące takie kierunki myśli politycznej, jak komunizm, anarchizm i nacjonalizm. Ten ostatni stał się przedmiotem ożywionych debat politycznych z udziałem polityków reprezentujących partie głównego nurtu. Stał się także elementem programów ugrupowań o charakterze populistycznym. Nacjonalizm jest jednak przede wszystkim kanwą programów partii politycznych, które w państwach Unii Europejskiej wyznaczają kierunki antyunijnego myślenia politycznego, a ich postulaty nierzadko zyskują akceptację wyborców rozczarowanych dotychczasową polityką integracyjną.

\section{Polscy nacjonaliści wobec Unii Europejskiej}

Wartością pierwotną w nacjonalizmie jest naród, żyjący w państwie jako jego formie organizacyjnej, które winno realizować jego interesy. Jednak nie każda myśl odwołująca się do wartości narodowych jest myślą nacjonalistyczną. W przypadku Polski myś1, która prezentowała umiarkowany program interesu narodowego, zawierała koncepcje walki politycznej opartej na zachodnioeuropejskiej demokracji parlamentarnej i odwoływała się do społecznej nauki Kościoła katolickiego, określana jest mianem myśli narodowej. Z kolei myśl nacjonalistyczna, bazująca na fundamencie narodowym, skłaniała się ku ortodoksji religijnej, optowała za integryzmem religijnym i stosowała skrajną retorykę (Maj, 2008, s. 114-115). Wartość narodu konstytuuje także nacjonalistyczną koncepcję przywiązania do niego, a w szczególności lojalności, która przewyższa inne przywiązania i lojalności (Kuczur, 2008, s. 77). Niejednoznaczności w definiowaniu terminu ,naród”, jego pojemność i zakres, a także różnice znaczeń językowych, wpływają na wielość stosowanych w nauce klasyfikacji nacjonalizmów i ich typów oraz zróżnicowane interpretacje w zakresie ich wartościowania. Podstawowy podział nacjonalizmów europejskich obejmuje nacjonalizmy etniczne, kulturowe i statokratyczne (Bäcker, 2011, s. 170-173). Wszystkie te rodzaje nacjonalizmu można odnaleźć we współczesnej europejskiej myśli politycznej.

W Polsce do grona partii nacjonalistycznych, które funkcjonowały w końcu XX wieku i na początku kolejnego stulecia zaliczyć można m.in. Polską Wspólnotę Narodową - Polskie Stronnictwo Narodowe (PWN-PSN), którego geneza tkwi w okresie 
Polski Ludowej, ale szczególną aktywnością wyróżniało się w latach dziewięćdziesiątych XX wieku, Stronnictwo Narodowe „Szczerbiec” (SN „Szczerbiec”), które jako partia polityczna zostało zarejestrowane w 1990 roku, oraz Narodowe Odrodzenie Polski (NOP), które działa od 1981 roku (Maj, 2008). Ich stanowiska wobec integracji europejskiej z udziałem Polski uzupełniała bogata publicystyka internetowego „Dziennika Narodowo-Radykalnego Nacjonalista.pl".

Dla PWN-PSN Unia Europejska stanowiła przejaw globalizmu, germanizacji i realizacji niemieckiej polityki określanej hasłowo, jako „Drang nach Osten” (parcie na Wschód). W referacie przygotowanym w 2002 roku na międzynarodową konferencję Polska, Czechy, Słowacja, Serbowie Lużyccy - możliwości i perspektywy współpracy i rozwoju, Bolesław Tejkowski przewodniczący PWN-PSN uznał, że globalizm jest najwyższym stadium kapitalizmu i imperializmu. Wiązał go z dominacją Stanów Zjednoczonych i Unii Europejskiej nad światem. Według niego przejawiał się w podporządkowywaniu innych państw i narodów, a także pozbawianiu ich suwerenności i tożsamości narodowej. Przejawem globalizmu miało być także „przywłaszczanie” gospodarek i ziemi wchłanianych państw, ograniczanie ich produkcji i „,zalewanie” towarami, a dalej ich „wyzyskiwanie” i ostatecznie „niszczenie”. Globalizm interpretowany był przez Tejkowskiego jako proces, który zapewnia zysk bogatej mniejszości przez wyzysk biednej większości, a zbrojnym orężem bogatych państw miał być Pakt Północnoatlantycki (Tejkowski, 2002).

Po wstąpieniu Polski do Unii Europejskiej, w referacie Zwycięstwo nad faszyzmem przestaniem jedności słowiańskiej, przygotowanym na IX Swiatowy Sobór Narodu Rosyjskiego w Moskwie, Bolesław Tejkowski pisał, że łupem globalizmu stały się Polska, Czechy, Słowacja, Węgry, Słowenia, Litwa, Łotwa i Estonia, które zostały zintegrowane z Unią i Paktem Północnoatlantyckim. Według niego Czechom i Polsce grozić miała utrata ziem zachodnich na rzecz Niemiec. Państwa, które wstąpiły do Unii Europejskiej stracily część majątku narodowego, który został przejęty przez zachodni kapitał. Ograniczona została produkcja, wzrosło bezrobocie i nędza społeczeństw nowych członków Unii. Co szczególnie ważne w słowach Tejkowskiego, państwa te miały być przeciwstawiane Rosji i wykorzystywane do wspierania zbrojnych agresji amerykańskich, czego przykładem miała być wojna w Iraku. Przejawem ekspansji globalizmu było i to, że do procesu integracji europejskiej zamierzano włączyć Ukrainę i Białoruś, a zatem także przeciwstawić te państwa Rosji. Celem takich działań miało być osłabienie Rosji i narzucenie jej globalistycznego ustroju, zachodniej demokracji i prozachodniej władzy. To doprowadzić miało do przejęcia rosyjskiego majątku narodowego przez zachodni kapitał i rozbicia Federacji Rosyjskiej na kilka odrębnych państw (Tejkowski, 2005).

Snując wizję alternatywnego wobec Unii Europejskiej związku państw, przewodniczący PWN-PSN pisał o Wspólnocie Słowiańskiej, opartej na jednej preetnicznej więzi plemiennej: „Będzie to wszechstronne przymierze gospodarcze, naukowe, techniczne, polityczne, wojskowe i ogólnocywilizacyjne wszystkich Narodów i Państw Słowiańskich - wolnych Narodów i suwerennych Państw, otwarte dla innych Narodów geograficznie i historycznie związanych ze Słowiańszczyzną. Będzie to Związek Państw Słowiańskich, tworzony w oparciu o największy i najbogatszy obszar Świata, o etniczno-kulturowe pokrewieństwo, o słowiańską duchowość stanowiącą realną siłę 
cywilizacyjnego rozwoju, o mocarstwową pozycję Rosji gwarantującej bezpieczeństwo całej Słowiańszczyźnie. [...] Słowiańskie przymierze gospodarcze, naukowe i techniczne może i musi wytworzyć jeden z największych organizmów gospodarczych i rynków Świata, zapewnić Słowiańszczyźnie rozwój oraz przodującą rolę w tworzeniu nowoczesnych technologii, dać dobrobyt wszystkim Słowiańskim Narodom i ich obywatelom. [...] Słowiańskie przymierze polityczne i wojskowe ma wypracować wspólne wartości oraz zasady życia i rozwoju naszych Narodów, określić wspólny stosunek do Europy i Świata, powołać do życia nowy ustrój sprawiedliwości społecznej, przeciwstawny kapitalizmowi stosującemu wyzysk narodowy i klasowy. Podstawą ustroju sprawiedliwości będzie suwerenność państwowa, władza zależna wyłącznie od własnego Narodu, własność ziemi i fabryk dostępna tylko dla własnego Państwa i własnych obywateli, pełne zatrudnienie stanowiące czynnik zrównoważonego rozwoju i upowszechnienia dobrobytu. Tego ustroju oraz Narodów i Państw Słowiańskich mają strzec samodzielne wojska narodowe i samodzielny przemysł zbrojeniowy. [...] Agresor musi wiedzieć, że w razie wojny choćby tylko z jednym Słowiańskim Narodem będzie miał do czynienia nie tylko z wojskami wszystkich Państw Słowiańskich, ale również z całymi Narodami umiejącymi i chcącymi bronić swej Słowiańskiej Ziemi. [...] Początkiem i podstawą Wspólnoty Słowiańskiej, zrzeszającej wszystkie Narody i Państwa Słowiańskie, jest tworzenie Południowego, Zachodniego i Wschodniego Związku Państw Słowiańskich" (Tejkowski, 2001).

Z innej perspektywy integrację europejską oceniało SN ,Szczerbiec”. I tu jednak „Zachód" postrzegany był jako zmierzający do włączenia do swojej strefy wpływów terytoriów wschodniej części kontynentu, sięgających po Ural lub dalej. Dlatego też Polskę ustanowiono przedsionkiem Europy. Miało być to przejawem realizacji planów masońskich, mających na celu uczynienie w przyszłości z Polski kolonii zdemoralizowanego i niechrześcijańskiego Zachodu. W latach dziewięćdziesiątych XX wieku, a więc w toku procesu zmierzającego do zintegrowania Polski ze Wspólnota, władze Rzeczypospolitej oskarżane były przez SN „Szczerbiec" o prowadzenie świadomej polityki likwidacji gospodarki i niszczenia oporu światlych członków narodu. Tego typu argumenty szły w parze $\mathrm{z}$ informacjami o zagrożeniu ze strony Niemiec, o garnizonach niemieckich wojsk rozlokowanych na ziemiach polskich, o niemieckich towarach, które zalewały polski rynek i o broni jądrowej, która, kiedy pojawi się w Polsce, narazi kraj na zagrożenie wojenne (Maj, Maj, 2007, s. 123).

Podobnie jak PWN-PSN odwoływała się do idei jedności narodów słowiańskich na czele z Rosją, tak też i SN „Szczerbiec” pozytywnie odnosiło się do współpracy dwóch bratnich narodów słowiańskich, polskiego i rosyjskiego. Polska i w przyszłości Rosja miały stać się ośrodkami oporu wobec Unii Europejskiej. Inaczej jednak niż w enuncjacjach przewodniczącego PWN-PSN, SN „Szczerbiec" nie bazowało na argumentach preetnicznej więzi plemiennej, ale na obawach związanych z ekspansją NATO i Wspólnoty Europejskiej. W koncepcjach Stronnictwa stosunki między narodami polskim i rosyjskim powinny zostać oparte na zasadach równości, suwerenności, dobrego sąsiedztwa i wzajemnego poszanowania swoich interesów. Taka wizja nie była jednak jednoznaczna i trwała. Sprzeczne z nią były opinie wyrażane w łonie partii o próbach rosyjskiej hegemonizacji Polski, a także koncepcje SN, dotyczące rewizji wschodniej granicy Polski w duchu powrotu na dawne terytorium (Maj, Maj, 2007, s. 122-123). 
PWN-PSN odwoływała się do wspólnej religijnej tradycji przedchrześcijańskiej plemion słowiańskich. Miała ona jednoczyć je w opozycji wobec cywilizacji zachodnioeuropejskiej, a więc cywilizacji obcej Słowianom. Z kolei SN „Szczerbiec” pozytywnie odnosiło się do tradycji Kościoła katolickiego, ale przedsoborowego. Natomiast dla NOP religia stanowiła rudymentarny wyznacznik Zasad ideowych nacjonalizmu, które jako jeden $z$ dokumentów programowych partii stanowiły kanwę, na której zasadzał się program NOP i organizowana była jego działalność. Zgodnie z tym dokumentem celem absolutnym dla nacjonalistów może być tylko Bóg, jako wartość stała oraz źródło norm i praw kształtujących życie jednostki i wspólnoty. Człowiek interpretowany jako istota społeczna nie może rozwijać się poza wspólnotą ludzi. Ta zaś, zgodnie z tekstem Zasad ideowych nacjonalizmu, „nie jest sumąjednostek, lecz całością, w której człowiek realizując swój cel absolutny korzysta i wzbogaca swe życie o osiagnięcia innych ludzi". Wspólnotą naturalną i najwyższego typu jest natomiast naród, który ,jest dobrowolnym, opartym na więzi psychicznej i moralnej związkiem ludzi posiadających - wynikające ze wspólnych przodków i historycznej tradycji - poczucie odrębności kulturowej i chęć jej zachowania oraz rozwoju". Naród posiada określone prawa, jak: prawo zachowania własnego języka i kultury, prawo kontroli wychowania narodu, prawo do terytorium narodowego przynależnego z tradycji i historii, prawo do powoływania struktur mu podległych, w tym struktury wyższego rzędu, jaką jest państwo, które nie może działać w sprzeczności z prawem naturalnym (Zasady ideowe nacjonalizmu).

Opierając się na tych wskazówkach NOP opracowało Zasady programowe, określające cele partii. Zgodnie ze słowami tego dokumentu partia „nie działa na rzecz naprawy istniejącego ustroju, gdyż nie da się uratować rudery, trzymającej się w całości jedynie dzięki żelaznym obręczom ekonomicznego ucisku i policyjno-politycznych represji”. NOP „wyznaczyło sobie za główny cel budowę Nowego Państwa - kraju, którego gospodarzem są jego mieszkańcy, a nie skorumpowana, pozbawiona wszelkiej kontroli kasta polityczna". Zmierza do budowy ładu narodowo-państwowego opartego na cywilizacji łacińskiej, której jednym z elementów, analizowanym w kontekście europejskim, jest „niezależne od zewnętrznych ośrodków decyzyjnych Państwo, gwarantujące wolności narodowe $\mathrm{w}$ stosunkach wewnętrznych i reprezentujące interesy swych obywateli na arenie międzynarodowej”. W tym względzie partia wyznaczyła sobie plan działań, które mają zmierzać do uporządkowania stosunków własnościowych, przede wszystkim poprzez wprowadzenie w kraju zasad powszechnego uwłaszczenia oraz poprzez przeprowadzenie reprywatyzacji ,zagrabionego i wyprzedanego ponadnarodowym molochom gospodarczym majątku narodowego", wprowadzenie ścisłej kontroli banków, a także zaprzestanie spłat zadłużenia zagranicznego. W kwestii stosunku wobec Unii Europejskiej NOP proponuje „,wprowadzenie zakazu działania grup, organizacji, partii, ośrodków informacji i propagandy uprawiających polityczną prostytucję na rzecz obcych państw i istniejących poza Krajem struktur władzy - w pierwszym rzędzie dotyczy to tych, którzy prowadzą akcję na rzecz likwidacji Państwa Polskiego i wchłonięcia go przez Unię Europejską". NOP żąda także usunięcia z Polski obcych jednostek wojskowych. Mogą one bowiem stanowić zagrożenie wewnętrzne, co związane jest $\mathrm{z}$ możliwością siłowego narzucania Polsce obcych interesów, i zewnętrzne, przejawiające się w możliwości organizowania prowokacji przeciwko innym 
państwom z obszaru Polski. Partia postuluje ,natychmiastowe zerwanie wszelkich działań »integracyjnych« z Unią Europejską, prowadzących do likwidacji Państwa Polskiego". Według jej Zasad programowych Polska powinna wiązać się układami polityczno-gospodarczymi z innymi, ale tylko na warunkach partnerskich i zgodnie z interesami narodowymi. Niedopuszczalne jest natomiast, aby ceną jakichkolwiek układów międzypaństwowych była utrata niezależności państwa (Zasady programowe).

W przemówieniu ideowo-programowym, wygłoszonym podczas konferencji Europejskiego Frontu Narodowego, zatytułowanym Nowoczesny nacjonalizm, Adam Gmurczyk - prezes Rady Wykonawczej NOP, sprecyzował wizję kształtu Europy, różnej od tej, która tworzona jest w ramach Unii Europejskiej. Dla NOP zatem celem jest zbudowanie Europy Państw Narodowych, które pozostają niezależne od sztucznych zwierzchności politycznych. Gmurczyk mówił: „Prawdziwa Europa, to kontynent suwerennych państw, kierowanych zgodnie z interesami swych nacji; państw zbudowanych na odwiecznych zasadach cywilizacji chrześcijańskiej. [...] To cywilizacja chrześcijańska ukształtowała nowoczesne narody, wpoiła im uniwersalną etyke, dała siłę rodzinie, zapewniła wolność ekonomiczną i społeczną całej wspólnocie europejskiej. Mówimy: Europa chrześcijańska - i rozumiemy przez nią prawdziwe chrześcijaństwo, mocne dumą i siłą narodów, a nie skorodowany system pseudochrześcijańskiej filozofii, który z ludzi czyni bezwolny motłoch, posłuszny władcom nowego porządku światowego. Pokazała historia, że wtedy, kiedy chrześcijaństwo było deptane, deptane były i prawa i wolność narodowa". Prezes NOP winą za dwie wojny światowe wywołane wbrew interesom narodów, obarczył ówczesny establishment i imperialistów. Uznał, że współcześnie nie ma w Europie znaczących tendencji rewizjonistycznych i szowinistycznych. Wyjątkiem pozostają Niemcy i Rosja, gdzie nadal kultywowany jest prymitywny i archaiczny imperializm dziewiętnastowieczny. Według Gmurczyka współczesna Europa zdominowana została przez „chory system” Unii Europejskiej. Jest to quasi-państwowa organizacja, której celem jest całkowite zniszczenie narodów i ich państw (Gmurczyk).

NOP, które jest członkiem International Third Position (ITP), międzynarodowej platformy grupującej organizacje i partie polityczne odwołujące się m.in. do idei i zasad nacjonalistycznych, identyfikowało się z jej deklaracją programową, którą współtworzył Adam Gmurczyk. Koncepcja świata przedstawiona w deklaracji to 10 punktów, które zawierają zasady prymatu ducha nad materią, porządku moralnego, opozycji wobec materializmu, negacji syjonizmu i wsparcia narodu palestyńskiego, koncepcje rządów powszechnych, decentralizacji i bezpośredniego podejmowania decyzji przez naród, stwierdzenia dotyczące uznania różnic rasowych i kulturowych, koncepcję rasowego separatyzmu, projekty zachowania otoczenia i natury, ostrzeżenia przed lichwą banków i międzynarodową finansjerą, odniesienia do dystrybucjonizmu i korporacjonizmu jako alternatywy dla kapitalistycznego systemu własności, wezwanie do rewolucji narodowej na świecie (Deklaracja Trzeciej Pozycji).

Teksty autorstwa członków NOP publikowane były również w portalu „Dziennik Narodowo-Radykalny Nacjonalista.pl”. Wśród publikacji zamieszczanych na stronach dziennika w latach 2010-2015, dwie zwracają szczególną uwagę, będąc odzwierciedleniem stanowiska NOP wobec Unii Europejskiej. Pierwsza z nich została zatytułowana UE trzeba zniszczyć, a nie reformować-stanowisko w sprawie eurowyborów. 
W dokumencie tym przypomniany został list otwarty polskich nacjonalistów pt. W obronie wolności, opublikowany w czasopiśmie „Szczerbiec” w 1996 roku. Jego autorzy pisali wówczas o tym, że zjednoczona Europa likwiduje atrybuty niepodległości państw, jak polityka zagraniczna, kontrola nad wojskiem i policja, czy kreowanie własnego prawa. W takiej Europie Polska staje się jedną z wielu prowincji geograficzno-ekonomicznych. Nie będąc przeciwko zawieraniu umów międzynarodowych, nacjonaliści odrzucili jednak ideę zjednoczonej Europy nie dlatego, że jest układem międzynarodowym, ale dlatego, że ich zdaniem właśnie nim nie jest. Dla nacjonalistów zjednoczona Europa stanowiła super-państwo, podporządkowane konkretnym interesom politycznym i ekonomicznym ponadnarodowych ośrodków finansowych. „Polska będzie niepodległa lub nie będzie jej wcale” - ostrzegali nacjonaliści (UE trzeba zniszczyć).

Niespełna dwie dekady później członkowie NOP uznali, że powyższa analiza okazała się prorocza. W okresie poprzedzającym wybory do Parlamentu Europejskiego w 2014 roku krytycznie odnieśli się do komitetów wyborczych o programie integracyjnym, ale także negatywnie ocenili te eurosceptyczne ugrupowania, które nadużywały przymiotników „patriotyczny”, „niepodległościowy”, albo „narodowy”. W analizowanym oświadczeniu NOP przypomniało, że jego celem jest zlikwidowanie Unii i stworzenie Europy Wolnych Narodów, które w niepodległych państwach będą realizowały cele wspólnot narodowych (UE trzeba zniszczyć).

W kolejnym tekście, opublikowanym w dzienniku „Nacjonalista.pl” już po wyborach do Parlamentu Europejskiego, Adam Gmurczyk z NOP odniósł się do niskiej frekwencji wyborczej w Polsce i braku zainteresowania Polaków wyborami i aktywnym członkostwem w Unii. Stworzył przenikniętą sarkazmem listę 20 zaleceń, które należy realizować, aby Unia zyskała poparcie rodaków. Oto kilka z nich: „Należy rozwiązać wszystkie instytucje unijne, gdzie banda darmozjadów przeżera pieniądze ze składek unijnych”, „Należy przestać pobierać składki unijne, bo więcej dajemy, niż odbieramy, a jak już coś odbieramy, to i tak zwykle każą nam robić za te pieniądze to, na co nie mamy ochoty”, „Należy wydać Polsce wszystkich »polityków«, którzy najpierw okradli kraj, za łapówki wyprzedali majątek narodowy, a teraz schronili się w Brukseli. Należy im się »czapa« a nie pensje z naszych pieniędzy”, ,Zakaz produkcji tradycyjnych oscypków i wędzenia kiełbasy czy obowiązek wyrzucania niesprzedanego pieczywa może sobie każdy uniokrata wprowadzać we własnym domu, od naszych przepisów z dala!”, „Nie będziemy brać udziału w wojnach z ludźmi, których nie znamy, do których nic nie mamy, którzy nic złego nam nie zrobili. I nie zamierzamy płacić za to, żeby ich zabić”, „Kura ma znosić jajka bez dużego kodu kreskowego, za to z dużym żółtkiem”, „Będziemy uprawiać tyle ziemniaków i łowić tyle ryb, ile potrzebujemy”, „Iran i Syria to kraje, które nie wysyłają do Europy swoich turbanów. I dlatego nie zamierzamy ich atakować. Natomiast bardzo chętnie napadniemy na Arabię Saudyjską - nie dosyć, że to nasz kosztowny sojusznik, to jeszcze podsyła nam turbaniarzy i płaci za ich meczety". Inne dotyczyły niechęci wobec Izraela, Kosowa i Turcji, a także homoseksualistów, którym autor proponował leczenie lub osiedlenie na Madagaskarze, wolności handlu, polityki wojskowej, satyry na unijne przepisy dotyczące krzywizny banana i klasyfikacji marchwi w kontekście sporu o to, czy jest warzywem, czy też owocem (Gmurczyk, 2014). 
Powyższe oświadczenia były przejawem rozumienia suwerenności narodowej i państwowej w duchu antyunijnym i antyglobalizacyjnym. Są one potwierdzeniem sprzeciwu wobec integracji europejskiej interpretowanej jako element procesów globalizacyjnych we współczesnym świecie. Dla Adama Gmurczyka realizacja programu NOP oznaczać miała zatem powrót do Europy opartej na egzystencji wielu organizmów państwowych, w odróżnieniu od Unii ciążącej ku jednej ponadpaństwowości i wymieszaniu różnych kultur. Unia bowiem służyć miała interesom nie narodu, ale biurokracji, finansistom i elitom ponadnarodowym.

Dziennik „Nacjonalista.pl” zwracał uwagę także na inne, często graniczące z absurdem, wady Unii Europejskiej. Wśród bieżących problemów, którymi zajmowali się publicyści portalu, znalazły się m.in.: rosnące bezrobocie i zagrożenie ubóstwem, problemy edukacji ludzi młodych, także w kontekście braku możliwości nauki krytycyzmu wobec Unii, brak wolności produkcji i kary za nadprodukcję towarów, niekorzystny dla Polski system podejmowania decyzji, brak akceptacji wśród Polaków dla waluty euro, unijna polityka klimatyczna, laicyzacja i ateizm, gaże parlamentarzystów unijnych, działalność policji europejskiej, imigracja, stanowiska partii nacjonalistycznych w innych państwach wobec integracji europejskiej.

Przedmiotem zainteresowania nacjonalistów w Europie stał się również islam. W Polsce dziennik „Nacjonalista.pl” podjał ten temat właśnie w kontekście europejskim. Niektóre teksty publikowane w portalu wskazywały na zagrożenia wynikające z odejścia Europy od korzeni chrześcijańskich, związane z coraz częstszym dominowaniem muzułmanów na lokalnych szczeblach władzy, wskazywany był także syjonizm, a nie islamizm, jako zagrożenie. Inne publikacje obwiniały kapitalizm i kapitalistów za wykorzystywanie ekstremistów islamskich jako narzędzie uzasadniające bądź usprawiedliwiające ekspansję Zachodu.

W kontekście integracji europejskiej szczególne miejsce wśród publikacji dziennika „Nacjonalista.pl” zajęły stosunki polsko-niemieckie, przede wszystkim zaś relacje między NOP a niemieckimi nacjonalistami z Narodowodemokratycznej Partii Niemiec (Nationaldemokratische Partei Deutschlands - NPD). Analiza publikacji dziennika prowadzi do wniosku, że polscy nacjonaliści z uwagą śledzili działania i ewolucję zainteresowań NPD. Ton publikacji o NPD cechowała rewerencja, choć zaznaczyć należy, że obejmowała ona NPD wyłącznie jako partię będąca jedną z wielu organizacji w Europie o programie nacjonalistycznym, a więc antyunijnym i antyglobalizacyjnym. Polscy nacjonaliści odrzucali bowiem pretensje aktywistów niemieckich, kierowane wobec ziem zachodnich Rzeczypospolitej. Stąd w kategoriach humorystycznych należy interpretować opublikowany w dniu 1 kwietnia 2013 roku komunikat zatytułowany Negocjacje z NPD zwieńczone sukcesem. „Mamy sojusz”, w którym stwierdzono m.in.: „W ramach sojuszu uzgodnione zostały warunki ponownego plebiscytu w mieście Gdańsk, kwestia uszanowania mniejszości niemieckiej na terenie woj. opolskiego, status aryjski dla Polaków w przyszłej, odrodzonej Rzeszy i nie tylko. Strona polska gorączkowo chce przekazać pod zarząd tymczasowy miasto Breslau niemieckiej administracji [...]" (Negocjacje z NPD).

Zarówno program NPD, choćby ten z początkowych lat działalności partii w latach sześćdziesiątych XX wieku (Maćkowiak, 1983), późniejsze enuncjacje jej polityków, jak i współczesne wypowiedzi liderów, nie pozwalają na alians, który ignoruje problem 
granicy polsko-niemieckiej. Całkiem niedawno Udo Pastörs z NPD stwierdzil, że „Na razie Polska z Niemcami ma jedynie zawieszenie broni. Między naszymi krajami nie został podpisany żaden ważny traktat międzynarodowy. Stan wojny trwa" (Sterlingow, Wąs, 2006, s. 2). Dlatego też polscy nacjonaliści nazywają relacje z nacjonalistami niemieckimi „zaognionymi” ze względu na specyficzną politykę wschodnią tych drugich (Niemieccy nacjonaliści). W odniesieniu do roszczeń wobec Śląska i innych ziem należących do Polski, wysuwanych przez radykalnych nacjonalistów i neonazistów niemieckich, publicysta dziennika „Nacjonalista.pl” uznał, że nie można pozwolić na realizację takich żądań w imię jedności nacjonalistów. Wyraził jednak zrozumienie dla niemieckich tęsknot wobec terenów nadodrzańskich na zasadach, podobnych do tych, które Polacy odczuwają wobec Kresów Wschodnich. Zauważył, że nie można mieć o nie pretensji, jeśli nie stają się postulatami politycznymi (VonSchwarzau).

Zarówno polscy, jak i niemieccy nacjonaliści odnajdują jednakże łączącą ich nić w działaniach przeciwko wspólnym wrogom. W przytaczanym wcześniej fragmencie tekstu o zaognieniu relacji między polskimi i niemieckimi nacjonalistami w odniesieniu do polityki wschodniej nacjonalistów niemieckich, autor komentarza uznał drugorzędność tego problemu. Wskazał bowiem na konieczność przyłączenia się do wspólnego frontu walki w obronie syryjskiego rządu Baszara al-Assada, który został uznany za sojusznika nacjonalistów w walce z New World Order (Niemieccy nacjonaliści). Na odsunięcie w czasie problemu granicy polsko-niemieckiej zwrócił uwagę także Frank Franz, wybrany przewodniczącym NPD w 2014 roku. W wywiadzie dla dziennika „Nacjonalista.pl” mówil: „W chwili obecnej jesteśmy świadkami zmian na szczeblu politycznym i społecznym. Stanowią one dla nas znacznie większy problem aniżeli zadawnione spory terytorialne i graniczne. Jeżeli nie obronimy się przed tym zagrożeniem, to stare konflikty nie będą miały dłużej żadnego znaczenia. Wspólnie musimy zażegnać niebezpieczeństwo ciążące nad naszymi narodami, które nastaje na nas od zewnątrz. Dla nas największym zadaniem jest suwerenność i wolność Niemiec. Dopóki nie uzyskamy całkowitej suwerenności, dopóty nie będziemy w stanie rozwiązać pozostałych egzystencjalnych kwestii (Musimy walczyć razem).

Dla polskich i niemieckich nacjonalistów to zatem Unia Europejska jest ich wspólnym przeciwnikiem.

\section{Unia Europejska w programie niemieckich nacjonalistów}

Niemieckie partie mieszczące się na skrajnych antypodach nurtu nacjonalistycznego określane są w tamtejszych badaniach zazwyczaj jako prawicowo-ekstremistyczne (rechtsextrem). Zestawiając różne warianty pojęcia „ekstremizm”, Gero Neugebauer zauważa, że za ekstremizm prawicowy mogą uchodzić postawy negujące zasadę fundamentalnej równości ludzi (Neugebauer, 2001, s. 14). Z kolei Birgit Rommelspacher pisze, że ekstremizm prawicowy ma charakter antydemokratyczny, rzuca wyzwanie parlamentaryzmowi, który pragnie zastąpić autorytarnymi formami rządów, za zjawisko naturalne zaś uważa hierarchię płci, narodów i ras (Rommelspacher, 2002, s. 132). W niemieckich badaniach można spotkać się z podziałem na prawicę demokratyczną (demokratische Rechte) oraz skrajną prawicę (extreme Rechte) (Braun, Geisler, Ger- 
ster, 2009, s. 15). Natomiast na stronach internetowych niemieckiego Urzędu Ochrony Konstytucji (Bundesamt für Verfassungsschutz) można przeczytać, że prawicowy ekstremizm w Niemczech nie stanowi jednolitej struktury, lecz składa się z rozmaitych składników ideologicznych: narodowych, rasistowskich, antysemickich oraz antyislamskich. Jego wspólnym mianownikiem jest zazwyczaj idea homogenicznej etnicznie wspólnoty narodowej (Volksgemeinschaft). Do ruchów skrajnej prawicy zaliczane są ugrupowania zarówno nielegalne, jak i legalnie działające partie, takie jak Narodowodemokratyczna Partia Niemiec (Nationaldemokratische Partei Deutschlands), Prawica (Die Rechte) czy północnonadreńsko-westfalski Ruch Obywatelski pro NRW (Bundesamt für Verfassungsschutz, 2015; na temat idei Volksgemeinschaft por. Brandstetter, 2012, s. 18-19).

W pierwszych latach istnienia Republiki Federalnej Niemiec otwarte odwoływanie się do ideologii nazizmu było zabronione, jednak środowiska skrajnej prawicy próbowały znaleźć swoje miejsce na tamtejszej scenie politycznej. W skali ogólnokrajowej początkowo funkcjonowały Niemiecka Partia Konserwatywna - Niemiecka Partia Prawa (Deutsche Konservative Partei - Deutsche Rechtspartei - DKP-DRP) oraz Socjalistyczna Partia Rzeszy (Sozialistische Reichspartei - SRP), natomiast w skali regionalnej Partia Narodowodemokratyczna (Nationaldemokratische Partei - NDP) w Hesji oraz Zrzeszenie Odbudowy Gospodarczej (Wirtschaftliche Aufbau-Vereinigung - WAV) w Bawarii. Spośród nich jedynie Socjalistyczna Partia Rzeszy odnotowywała sukcesy, uzyskując w 1951 roku 11\% poparcia w wyborach do parlamentu krajowego Dolnej Saksonii i 7,7\% w wyborach do Zgromadzenia Obywatelskiego Bremy. Jednak już w 1952 roku została zdelegalizowana mocą orzeczenia Federalnego Trybunału Konstytucyjnego (FTK). Z kolei powstała w 1950 roku z połączenia dolnosaksońskiego odłamu DKP-DRP i heskiej NDP Niemiecka Partia Rzeszy (Deutsche Reichspartei - DRP) w wyborach do Bundestagu w 1953 roku uzyskała 1,1\%, zaś w 1963 roku wystawiając wspólną listę z Partią Niemiecką (Deutsche Partei - DP) w wyborach do Zgromadzenia Obywatelskiego Bremy otrzymała 5,2\% poparcia. Była reprezentowana także w parlamentach Dolnej Saksonii i Nadrenii-Palatynatu. Z początkiem lat sześćdziesiątych XX wieku zaczęła dojrzewać koncepcja zjednoczenia środowisk skrajnej prawicy, która została zrealizowana w 1964 roku z chwilą utworzenia Narodowodemokratycznej Partii Niemiec, stanowiącej współcześnie największą siłę skrajnej prawicy w Niemczech. Na jej czele stanął wówczas dotychczasowy przewodniczący DRP Adolf von Thadden. W kolejnych latach wprowadzała ona swoich przedstawicieli do parlamentów krajowych, zaś w 1969 roku uzyskała 4,3\% głosów w wyborach do Bundestagu - niewiele poniżej progu wyborczego (Pfahl-Traughber, 2009, s. 77-82).

Z początkiem lat siedemdziesiątych NPD popadła na dwie dekady w okres stagnacji. W tym samym czasie (1971 rok) utworzona została Niemiecka Unia Ludowa (Deutsche Volksunion - DVU), początkowo działająca jako stowarzyszenie, a od 1987 roku jako partia polityczna (Mudde, 2000, s. 60-80). Jej założyciel, Gerhard Frey, kierował nią aż do roku 2009. DVU, podobnie jak NPD, w różnych okresach miała swoich przedstawicieli w landtagach (w Brandenburgii, Bremie, Szlezwiku-Holsztynie i Saksonii-Anhalt). Obie partie chętnie współpracowały aż do ich zjednoczenia $z$ dniem 1 stycznia 2011 roku (Reißmann, 2011). Nie powiodła się zainicjowana jeszcze z początkiem 2001 roku przez rząd oraz Bundestag i Bundesrat próba likwidacji NPD, 
bowiem Federalny Trybunał Konstytucyjny w orzeczeniu z 18 marca 2003 roku zdecydował o wstrzymaniu procedury delegalizacji, orzekając m.in., że obecność tajnych współpracowników służb ochrony konstytucji w gremiach NPD uniemożliwia obiektywną ocenę programu i działań partii (Jansen, Birnbaum, 2003; treść orzeczenia: Beschluss vom 18. März 2003; szerzej na temat pierwszej próby delegalizacji NPD zob. Staud, 2006, s. 61-67). Dekadę później, 3 grudnia 2013 roku, Bundesrat ponownie zgłosił do FTK wniosek o delegalizację NPD (Jansen, 2013), natomiast w uchwale z 19 marca 2015 roku Trybunał nakazał doprecyzowanie materiału dowodowego w poszczególnych punktach (Beschluss vom 19. März 2015).

Po fuzji z NPD część członków DVU, przeciwnych zjednoczeniu obu partii, założyła w maju 2012 roku nową partię pod nazwą Prawica (Die Rechte), która -jak się wydaje - miała stanowić alternatywę dla NPD. Na jej czele stanął Christian Worch, znany wcześniej m.in. z zaprzeczania holokaustowi i działalności w różnych niewielkich ugrupowaniach neonazistowskich. Przedstawiciele nowej partii nie kryli się z tym, że program zaczerpnęli w głównej mierze w spadku po DVU (Wittrock, Diekmann, Hebel, 2012).

W 1983 roku na niemieckiej scenie politycznej pojawiło się nowe ugrupowanie pod nazwą Republikanie (Die Republikaner - REP). Wyłoniło się ono z prawego skrzydła CSU w następstwie niezadowolenia nazbyt ugodowa - jak uważali założyciele (Ekkehard Voigt, Franz Handlos, Franz Schönhuber) - polityką wobec NRD, w tym obietnicami kredytów dla państwa wschodnioniemieckiego, które miał poprzeć przewodniczący CSU, charyzmatyczny Franz Josef Strauß. Opinia partii nurtu skrajnej prawicy przylgnęła do niej na przełomie lat osiemdziesiątych i dziewięćdziesiątych XX wieku. Jej pierwszym poważniejszym sukcesem było wejście do władz krajowych Berlina w 1989 roku z wynikiem 7,5\%, a następnie Badenii-Wirtembergii w 1992 (10,9\%) i 1996 roku $(9,1 \%)$. Najlepszy rezultat w wyborach do Bundestagu Republikanie uzyskali w 1990 roku - 2,1\%, zaś w 1989 roku wprowadzili aż sześciu deputowanych do Parlamentu Europejskiego z rezultatem 7,1\%. W kolejnych latach pogłębiał się jednak trend spadkowy (Kailitz, 2009, s. 115-116).

Do większych legalnych ugrupowań uchodzących za mieszczące się w nurcie prawicowego ekstremizmu zaliczane są również tworzone od połowy lat dziewięćdziesiątych niejednolite ruchy obywatelskie określane wspólnym przedrostkiem „Pro-”, wśród których znajdują się zarówno partie polityczne, jak i stowarzyszenia (m.in. Pro Köln, Pro Deutschland, Pro NRW) (zob. Edathy, Sommer, 2009, s. 50-56). Stosunkowo najbardziej aktywna wydaje się być w ostatnim czasie północnonadreńska Pro NRW, wystawiająca kandydatów w wyborach samorządowych (z sukcesami), krajowych w Północnej Nadrenii-Westfalii oraz do Parlamentu Europejskiego. Z kolei Pro Deutschland ubiegała się o mandaty wyborcze w berlińskich władzach krajowych i lokalnych oraz krajowych w Saksonii.

Zjawisko prawicowego ekstremizmu stało się szczególnie po zjednoczeniu Niemiec przedmiotem żywego zainteresowania kregów politycznych, publicystycznych i naukowych, zwłaszcza, że postawy tego rodzaju, thumione w Niemieckiej Republice Demokratycznej, zaczęly się ujawniać w nowych krajach związkowych po reunifikacji państwa (choć zjawisko to nie ograniczało się do wschodniej części państwa). Liczba aktów przemocy na tle skrajnie prawicowym znacząco wzrosła w pierwszej połowie lat 
dziewięćdziesiątych, by z czasem nieco wyhamować (Rommelspacher, 2002, s. 133). Ugrupowania początkowo identyfikowane raczej z chuligańskimi wybrykami i atakami na cudzoziemców, z czasem przechodziły ewolucję zmierzającą do wpisania się w ramy konstytucyjnej rywalizacji politycznej i zrzucenia z siebie piętna ugrupowań gotowych do działań antysystemowych.

W wyborach do Parlamentu Europejskiego w 2014 roku spośród omawianych w artykule partii udział wzięły trzy: NPD, REP i Pro NRW. Z tego względu stosunkowo łatwo wyciagnąć wnioski odnośnie ich stosunku do integracji europejskiej, które będą przedmiotem dalszych rozważań. Także Prawica zamierzała wziąć udział w wyścigu o mandaty w wyborach europejskich, nie uzyskała jednak wystarczającej liczby podpisów, umożliwiającej wystawienie listy kandydatów (Speit, 2014). Jednak ze względu na plany wyborcze i określony stosunek do Unii Europejskiej, również będzie przedmiotem analizy.

Największą niemiecką legalną partią zaliczaną do prawicowego ekstremizmu jest NPD. W swoim głównym dokumencie programowym, uchwalonym na zjeździe w Bambergu 5 czerwca 2010 roku, niewiele miejsca poświęca sprawom europejskim, niemniej jednak opowiada się za umocnieniem suwerenności Niemiec i Europą narodów (Deutsche Souverenität und Europa der Völker). Posuwa się do twierdzenia, że rządzący odmawiają narodowi niemieckiemu prawa do decydowania o sobie, $m$.in. wiążąc się traktatem lizbońskim. Sprzeciwia się cedowaniu suwerennych praw państwowych na rzecz UE, uznawaną za „Europę koncernów i technokratów, stojącą w opozycji do idei Europy narodów, szanującej tradycję zachodnią i chroniącą tożsamość narodową" (Arbeit, s. 13). Znacznie obszerniejszym źródłem dokumentującym stosunek NPD do europejskich procesów integracyjnych jest program sporządzony przed wyborami do Parlamentu Europejskiego z 2014 roku. Jest to 33-stronicowy dokument, podzielony na osiem uszeregowanych tematycznie rozdziałów, poprzedzonych zawartym w preambule hasłem: „Tak dla Europy, nie dla takiej UE”. Następuje w nim odwołanie do tradycji zachodniej, nieprzypadkowo przywołane są zwycięstwa Karola Młota nad Arabami pod Poitiers (732 rok) i Jana III Sobieskiego nad Turkami pod Wiedniem (1683 rok), które stawiają Europę w opozycji do islamu. W dalszej części pojawia się zarzut, że przepisy europejskie przyczyniają się do obniżenia niemieckiej konkurencyjności. NPD krytykuje zjawisko imigracji do Europy (używając nawet pojęcia „przestępcza polityka imigracyjna”), domagając się jej wstrzymania „wszelkimi legalnymi i administracyjnymi środkami". UE jest m.in. obarczana winą za imigrację prowadzącą do infiltracji kontynentu przez obce kultury i tym samym stanowiącą zagrożenie dla jego dotychczasowej tożsamości. Imigranci -zdaniem NPD - nadużywają europejskiej polityki społecznej, która powinna leżeć w kompetencji poszczególnych państw, a nie UE. Islam zostaje odrzucony jako obcy europejskiej tradycji. Partia opowiada się za utworzeniem instytucji odpowiedzialnej za obserwację trendów demograficznych w Europie odnośnie zdolności reprodukcyjnych i problemów starzenia się społeczeństw. NPD przestrzega, że wysoki poziom obcej kulturowo imigracji w połączeniu z niskim przyrostem naturalnym Europejczyków stanowi poważne zagrożenie dla kontynentu (Europa wählt, s. 13-16).

Kolejne zarzuty wobec UE dotyczą sfery ekonomicznej. Unia obwiniana jest o nadmierną centralizację gospodarki, niejasne przepisy, które faworyzują wielkie koncerny 
i duże przedsiębiorstwa rolne kosztem mniejszych podmiotów. NPD odrzuca planowaną strefę wolnego handlu z USA, domaga się wspierania regionalnych kregów gospodarczych, większej przejrzystości systemu przyznawania subwencji określonym podmiotom przez UE, „mniej centralnego sterowania europejską gospodarką wewnętrzną przez brukselski reżim komisarzy", wzmocnienie współpracy gospodarczej (szczególnie w sektorze energii) z Rosją. NPD odrzuca również przygotowane w okresie kryzysu finansowego w Europie mechanizmy sanacyjne, takie jak Europejski Mechanizm Stabilizacyjny, unia bankowa, czy wsparcie dla Grecji. Domaga się przywrócenia narodowych suwerenności nad polityką pieniężna, w tym możliwości powrotu do walut narodowych. Obiektem krytyki jest także dorobek prawny Schengen, który zdaniem autorów programu, poprzez ułatwienie przekraczania granic przyczynił się do wzrostu przestępczości międzynarodowej w UE. Wskazuje się w szczególności granice Niemiec z Polską i Czechami jako wzorcowy przykład przenikania elementów przestępczych. NPD w kontekście napływu imigrantów ekonomicznych z Afryki ocenia granice UE jako praktycznie przepuszczalne. $Z$ drugiej strony krytykuje rozbudowę instrumentów prowadzących do nadmiernej kontroli nad obywatelami państw UE, co ma prowadzić do przekształcania się UE w "totalitarne państwo represyjne na wzór byłego ZSRR". Antidotum na te zjawiska powinno być przywrócenie kontroli na wewnętrznych granicach UE, ograniczenie imigracji (m.in. rozmieszczanie obozów dla imigrantów blisko zewnętrznych granic UE w celu łatwiejszego odsyłania ich do krajów pochodzenia), wstrzymanie pomocy socjalnej dla imigrantów, wstrzymanie rekrutowania pracowników spoza Europy, wzmocnienie granicznej agencji FRONTEX, zasadnicze zachowanie spraw z zakresu bezpieczeństwa wewnętrznego w narodowych kompetencjach, czy wreszcie ograniczenie instrumentów umożliwiających zbieranie i gromadzenie danych na temat obywateli państw UE (Europa wählt, s. 18-24).

NPD odnosi się także do zewnętrznych aspektów funkcjonowania Unii Europejskiej. Ubolewa nad - jak ocenia - podporządkowaniem UE hegemonialnej polityce USA, co grozi uwikłaniem się w konflikty z udziałem Waszyngtonu. Zaangażowanie UE w sprawy demokratyzacji Białorusi czy Ukrainy uważa za ingerencję w sprawy wschodnioeuropejskie, nie aprobuje amerykańskiego programu tarczy antyrakietowej. Domaga się zatem „,suwerennej” (niezależnej od USA) polityki, stworzenia „europejskiej linii obrony" chroniącej przed niekontrolowanym napływem uchodźców (na Morzu Śródziemnym, na Bałkanach i w Europie Środkowo-Wschodniej), umocnienia partnerstwa z państwami śródziemnomorskimi i przerwania negocjacji akcesyjnych z Turcją. W sferze unijnej Wspólnej Polityki Bezpieczeństwa i Obrony, NPD domaga się rozwiązania wszelkich wspólnych formacji wojskowych i całkowitego przeniesienia kompetencji w tym zakresie na szczebel narodowy, wycofania obcych, zwłaszcza amerykańskich, wojsk z Europy, zrewidowania zasad współpracy wywiadowczej i odrodzenia średniej wielkości przedsiębiorstw sektora zbrojeniowego oraz utworzenia bliżej niesprecyzowanego „europejskiego paktu obronnego jako platformy koordynującej politykę bezpieczeństwa UE" (Europa wählt, s. 25-33).

Ruch Obywatelski Pro NRW w swoim głównym dokumencie programowym w zasadzie nie ustosunkowuje się do integracji europejskiej, ewentualnych śladowych odniesień można doszukiwać się w haśle „Kształcenie zamiast imigracji” (drugi punkt programu), w którym postuluje poprawę systemu edukacji w Niemczech przy jedno- 
czesnym ograniczeniu imigracji i nadużywania prawa do azylu (Bürgerbewegung PRO $N R W, 2013)$. Stosunek Pro NRW do procesów integracyjnych w Europie nieco szerzej oddaje natomiast program tej partii opublikowany w kwietniu 2014 roku przed wyborami europejskimi, opatrzony wiele mówiącym tytułem Za Europq ojczyzn (Für ein Europa der Vaterländer). Jest to kilkunastostronicowa broszura, zawierająca główne tezy i postulaty Pro NRW. Już w samym wstępie przewodniczący partii Markus Beisicht odwołuje się do tytułowej „Europy ojczyzn” oraz chrześcijańsko-zachodnich tradycji kontynentu. W dalszej części argumentacja ta zostaje dodatkowo wzmocniona przywołaniem korzeni antycznych, wpływów germańsko-celtyckich, wartości chrześcijańsko-żydowskich i osiaggnięć oświecenia. Partia domaga się wzmocnienia zachodniej kultury i modelu państwa, wzmocnienia polityki prorodzinnej przy jednoczesnym ograniczeniu imigracji. Dość wyraźnie zaakcentowana jest niechęć do islamu, który traktowany jest jako obcy niemieckiej tradycji. Towarzyszy temu stanowisko odrzucające turecką kandydaturę do UE. Krytycznie oceniono aktualną politykę tureckiego rządu jako nastawioną na reislamizację państwa, jak również brak rozliczenia z ludobójstwem popełnionym na Ormianach w początkach XX wieku. W konsekwencji Pro NRW domaga się przerwania negocjacji akcesyjnych UE z Turcją oraz pozostaje na stanowisku niepodzielności Cypru. Partia domaga się ponadto bardziej restrykcyjnej polityki azylowej, posługując się pojęciem „oszustów azylowych” (Asylbetrüger) w odniesieniu do starających się o azyl w Niemczech. Zarzuca im nadużywanie niemieckich instrumentów polityki społecznej. Pro NRW chciałaby wzmocnienia unijnej agencji kontroli granic FRONTEX oraz wydalenia wszystkich nielegalnych imigrantów na koszt państw ich pochodzenia. Prawo do świadczeń socjalnych przysługiwałoby po otrzymaniu niemieckiego obywatelstwa lub dziesięcioletnim okresie zatrudnienia i płacenia podatków. Kolejnym celem ataków nadreńskiej partii są porozumienia z Schengen, które powinny zostać zrewidowane. Pro NRW postuluje przywrócenie kontroli granicznych, poprawę zwalczania przestępczości przygranicznej, zwłaszcza „przestępczych band z Europy Wschodniej i Południowej”. W jednym z punktów programu autorzy powracają do wzmiankowanego we wstępie islamu, twierdząc że „islamski ekstremizm jest obecnie największym zagrożeniem dla wolności i życia ludności Europy". Dlatego wśród żądań partii znajduje się zwalczanie tego zjawiska „wszelkimi środkami państwa prawa”, wydalenie islamskich kaznodziei nawołujących do nienawiści (Hasspredigern) oraz europejska współpraca na rzecz zwalczania terroryzmu międzynarodowego, jak i europejski zakaz działalności ugrupowań muzułmańskich salafitów. W dalszej części autorzy programu starają się dowieść, że „na szczeblu europejskim Niemcy są od lat celowo i systematycznie dyskryminowane", o czym świadczyć ma m.in. niesprawiedliwy podział miejsc w Parlamencie Europejskim. W związku z tym postuluje się ustanowienie niemieckiego językiem urzędowym UE, równouprawnienia Niemiec w Parlamencie Europejskim i reprezentowania interesów narodowych w tym gremium przez niemieckich deputowanych. W tej części przedmiotem krytyki staje się również unijna polityka wobec Rosji (w następstwie jej konfliktu z Ukraina), która leży „,w geopolitycznym interesie USA i pewnych kręgów panującego establishmentu UE, lecz nie w interesie Niemiec". Także następstwa kryzysu finansowego w UE są elementem programowym Pro NRW, która żąda wstrzymania pomocy finansowej dla Grecji, Hiszpanii i innych zadłużonych państw, rewizji umowy 
o Europejskim Mechanizmie Stabilizacyjnym, wiążących referendów w sprawie wystappienia zadhużonych państw ze strefy euro oraz sprzeciwia się redukcji długów. Co więcej, proponuje rozważenie powrotu do Deutsche Mark, odwołując się do czasów świetności tej waluty, kojarzonej z eksportową potęgą RFN. Jednocześnie Niemcy powinny chronić własną produkcję przed tańszymi towarami zza granicy, m.in. poprzez system lokalnych i regionalnych subwencji oraz politykę kontroli jakości wobec produktów importowanych. Ostatnie punkty programu koncentrują się wokół takich żądań, jak ,przejrzyste ujawnianie przychodów i wydatków administracji europejskiej i Parlamentu Europejskiego, odchudzenie brukselskiego aparatu urzędniczego o co najmniej 50\%, ograniczenie kompetencji prawodawczych Parlamentu Europejskiego", zaś przyjęte akty prawne powinny być każdorazowo ratyfikowane w drodze referendów. Nadreńskie ugrupowanie proponuje zresztą wprowadzenie instytucji wiążącego referendum w skali federalnej w Niemczech oraz możliwości odrzucania europejskich czy federalnych aktów prawnych w drodze powszechnego głosowania (jako modelowy przykład demokracji wskazana jest Szwajcaria). Partia ubolewa nad przekształceniem się UE z pierwotnej strefy wolnego handlu „w biurokratycznego molocha, który ciagle przywłaszcza sobie nowe kompetencje". W konkluzjach, w charakterze negatywnego przykładu przywołane są historyczne doświadczenia państw wielonarodowych (imperium rzymskie, Jugosławia), które do zguby doprowadziła ich narodowa heterogeniczność. Dlatego partia podkreśla znaczenie suwerennych państw narodowych, domaga się odwrotu od idei europejskiego państwa związkowego oraz postuluje ,przyjazną współpracę ludów i narodów zamiast ponadnarodowej papki jedności (Einheitsbrei)" (Für ein Europa, 2014).

Zbliżone elementy zawierają poglądy Republikanów. Obszerny program partii, noszący tytuł Spolecznie, patriotycznie, ekologicznie (Sozial, patriotisch, ökologisch) pochodzi z 2002 roku. W jednym z rozdziałów Republikanie opowiadają się za Europą ojczyzn i szczególną odpowiedzialnością Niemiec na rzecz zachowania i rozwoju europejskiego dziedzictwa kulturowego oraz przyjazną współpracą państw narodowych. Wśród nieco bardziej skonkretyzowanych postulatów znalazły się m.in.: zachowanie suwerenności państw członkowskich i przestrzeganie zasady subsydiarności w UE, prymat prawa krajowego nad europejskim, organizowanie referendum w przypadku nakładania na państwo zobowiązań wobec Wspólnoty oraz w przypadku rozszerzenia UE, utrzymanie Europy jako „ostoi chrześcijańskiego Zachodu”. Ponadto partia żąda reformy instytucjonalnej UE w celu ,zakończenia dyskryminacji Niemiec", m.in.: ograniczenia unijnego prawodawstwa wyłącznie do najważniejszych kwestii, ograniczenia prawa do azylu, redukcji instytucji unijnych, objęcia polityki rolnej z powrotem kompetencjami państw członkowskich, zmniejszenia wpłat państw członkowskich na rzecz UE, ustalenia liczebności miejsc w PE i KE odpowiadającej sile demograficznej poszczególnych państw, równouprawnienia języka niemieckiego z francuskim i angielskim, likwidacji euro i powrotu do DM. Republikanie oponują wobec członkostwa Turcji w UE. Sprzeciwiali się także „,członkostwu w UE państw wschodnio- i południowoeuropejskich, dopóki nie uznają dekretów Benesza i Bieruta za niebyłe". Odkurzyli również postulat „Europy rdzenia” (Kerneuropa), oznaczający de facto integrację różnych prędkości (Sozial, 2002, s. 14-15). Podobne postulaty, choć w znacznie bardziej zwięzłej postaci, za to w formie krótkich, krzykliwych haseł, zawieraja jednostronico- 
we quasi-programy zatytułowane Europa ojczyzn (Das Europa der Vaterländer) oraz Dla Republiki Niemieckiej-wyjść z tej UE! (Für die deutsche Republik-Raus aus dieser EU!). W tym ostatnim dokumencie pojawia się nawet pogląd, że „Europa musi zacząc od początku - a Niemcy muszą dać impuls ku temu".

W 2014 roku w obliczu wyborów komunalnych oraz do Parlamentu Europejskiego REP opublikowali dokument obejmujący skrócone tezy programowe. Wyrazem eurosceptycznego nastawienia tej formacji jest pojawiające się tam hasło: „Tak dla Europy - ale nie dla eurodyktatury!" (Ja zu Europa - aber nein zur Eurodiktatur!). Republikanie obszernie odnieśli się w dokumencie do kryzysu finansowego w UE. Kryzys określili jako „końcowy produkt fałszywej ideologii, w której to w centralnym miejscu stoją nie nasi obywatele, ale maksymalizacja zysków". Republikanie domagają się zatem m.in. większej kontroli nad sektorem finansowym, zwalczania skutków kryzysu z udziałem instytucji finansowych odpowiedzialnych za jego wybuch, czy odpowiedzialności prawnej poszczególnych banków, które popadły w tarapaty przez własną nieodpowiedzialną politykę finansową. REP domagają się także odpowiedzialności karnej polityków niemieckich, którzy zgodzili się na przyjęcie Europejskiego Mechanizmu Stabilizacyjnego. W dalszej części postulują rozbudowę współpracy gospodarczej pomiędzy regionami i państwami europejskimi oraz powiązanie wspierania regionów z reformami strukturalnymi i tworzeniem miejsc pracy. Zasadniczo sprzeciwiają się dalszemu cedowaniu prerogatyw państwowych na rzecz UE (30 Schwerpunkte, 2013, s. 5-6). Ponadto istotnym elementem programowym REP jest niechętny stosunek do imigracji połączony z żądaniem przywrócenia kontroli nad niemieckimi granicami i obawami przed wpływami radykalnego islamu, czego odzwierciedleniem są publikacje w dzienniku partii "Neue Republik” (zob. np. Asylpolitik aus, 2014; Salafisten und Dschihadisten, 2014).

Ostatnim z omawianych ugrupowań jest Prawica. Wpisuje się ona w skrajnie krytyczny nurt wobec UE, dowodząc „dyskryminacji” Niemiec w ramach europejskich procesów integracyjnych. Partia domaga się odejścia od unijnego modelu rolnictwa, tj. rezygnacji z dużych przedsiębiorstw rolnych i wzmocnienia małych rodzinnych gospodarstw, a także zmniejszenia niemieckich składek na rzecz UE (Programm der Partei DIE RECHTE, s. 7-8). Unia Europejska jest oceniana wysoce negatywnie, jako, ,zorganizowany wyzysk obywateli, prekursor międzynarodowego kapitalizmu, przeogromny biurokratyczny twór”, który oddala się „od praworządności i demokracji na rzecz interesów oligarchów i lobbystów. Suwerenność narodowa oddawana jest coraz bardziej na rzecz brukselskich biurokratów”. Prawica analizowała: „pełzającym celem zwolenników UE jest utworzenie europejskiego państwa z europejskim narodem. [...] Stanowczo odrzucamy UE w jej zwyrodniałej formie wraz z jej dyktatorskimi skłonnościami". Łatwo zatem zauważyć, że krytyka wobec UE w głównych punktach nie odbiega od innych partii skrajnej prawicy. Autorzy programu zapewniają jednak, że nie są przeciwnikami Europy. Pewnym novum na tle innych ugrupowań jest projekt powołania czegoś na kształt Związku Europejskiego (Europäischer Verbund). Opierałby się on na suwerennych państwach narodowych i odwoływałby się do kultury zachodniej. Wykluczone byłoby przystapienie kraju islamskiego lub pozaeuropejskiego. Poszczególne państwa dysponowałyby suwerennością w zakresie waluty, istniałyby kontrole graniczne, zwłaszcza w celu zwalczania nielegalnej imigracji i przestępczości 
międzynarodowej. Wskazana byłaby bliska współpraca gospodarcza, która wymagałaby zniesienia ceł. O przyjęciu kolejnych państw decydowałyby kraje członkowskie, każde państwo miałoby prawo opuszezenia Zwiazzu. Istniałby parlament, trybunał i inne instytucje. Utworzona zostałaby wspólna armia Związku (Programm der Partei DIE RECHTE, s. 18-19).

Programy omawianych czterech partii niemieckiej skrajnej prawicy dotyczące procesów integracji europejskiej charakteryzują się różnych poziomem szczegółowości. Dokument NPD, najbardziej rozbudowany, w miarę szczegółowo odnosi się do poszczególnych sektorów integracji, znamionując stosunkowo dobre przygotowanie merytoryczne jego autorów. Program Pro NRW omawia również rozmaite sektory integracji europejskiej, jednak raczej w sposób zwięzły i hasłowy. Z kolei Republikanie przed wyborami europejskimi skupili się głównie na kryzysie finansowym w UE, natomiast postulaty Prawicy są raczej zbiorem ogólników i niekiedy dość niespójnych haseł.

Podsumowując analizę programów wypada zauważyć kilka ich zasadniczych wspólnych cech, wśród których na pierwszym miejscu wyeksponować można skrajnie negatywne nastawienie do Unii Europejskiej. Antysemityzm z kolei został w nich wyraźnie stłumiony (co więcej, Pro NRW odwołuje się nawet do chrześcijańsko-żydowskich tradycji europejskich), na pierwszy plan wysuwa się natomiast antyislamizm połączony z ostrym sprzeciwem wobec obcej kulturowo imigracji, która ma stanowić główne zagrożenie dla przyszłości kontynentu. U NPD i Pro NRW znaleźć można także dość wyraźne akcenty antyamerykańskie. Ponadto w programach znajduje się wiele odwołań do różnych elementów europejskiego dziedzictwa kulturowego (m.in. myśli antycznej, chrześcijaństwa, oświecenia), natomiast całkowicie przemilczane są zbrodnicze doświadczenia III Rzeszy, które wszak stały się po 1945 roku impulsem na rzecz zachodnioeuropejskich procesów integracyjnych, zmierzających do utrwalenia pokojowego ładu na kontynencie. Jeśli występują odwołania do doświadczeń II wojny światowej, to raczej są one marginalne, np. w kontekście zrównania ich z dyktaturą SED (jak u REP), czy żądań przywrócenia dobrej pamięci o żołnierzach niemieckich, którzy mieli być tylko narzędziami w rękach polityków (jak w programie Prawicy).

Negatywne nastawienie do Unii Europejskiej podbudowane jest zazwyczaj żądaniami zakończenia rzekomej dyskryminacji Niemiec, jak np. postulat REP w sprawie proporcjonalnej w stosunku do liczby ludności reprezentacji poszczególnych państw w Parlamencie Europejskim. Autorzy takich pomysłów zdają się nie zauważać, że wprowadzenie takiej zasady (w miejsce obecnie obowiązującej reguly degresywnej proporcjonalności) doprowadziłoby do tego, iż pule miejsc w PE przypadające na największe państwa liczone byłyby w setkach (przy założeniu, że najmniejsze państwa miałyby po jednym deputowanym). Oznaczałoby to kolosalny rozrost Parlamentu Europejskiego, co stałoby w sprzeczności z innym postulatem REP, tzn. redukcją instytucjonalną UE. Podobnież domaganie się prymatu prawa krajowego nad prawem UE, w świetle dotychczasowych doświadczeń wypływających z ewolucji stosunków międzynarodowych jest obarczone błędem ignorancji. Prymat prawa międzynarodowego (w tym wypadku unijnego) nad krajowym (nie licząc konstytucji) jest bowiem powszechnie przyjętym aksjomatem, zaś jego zakwestionowanie podałoby w wątpliwość sens zawierania jakichkolwiek umów i zobowiązań międzynarodowych. $Z$ kolei proponowany przez Pro NRW model zatwierdzania unijnych aktów prawnych na drodze 
referendum prowadziłby do dysfunkcjonalności UE. Zdecydowaną przesadą jest również kierowany przez NPD zarzut centralnego sterowania gospodarką przez UE - dotyczy wszak organizacji, która aksjomatem swego modelu integracji ekonomicznej uczyniła zasady wolnego rynku. Z kolei Prawica formułując mgliste propozycje utworzenia Związku Europejskiego i przedstawiając jego konstrukcję nie zauważa, że większość propozycji (wspólny parlament, trybunał, zniesienie ceł, możliwość opuszczenia Związku) już istnieje właśnie w ramach UE. Co więcej - dążenie do rozluźnienia integracji i postulat wspólnej armii wydają się być dość niespójne. Odnosi się wrażenie, że te niekonsekwencje mogą być rezultatem dość powierzchownej wiedzy na temat europejskich procesów integracyjnych. Niewątpliwie UE stoi przed wyzwaniami reform np. w zakresie polityki azylowej, czy wdrożenia mechanizmów pozwalających na uniknięcie kryzysów finansowych, jednak etykietka prawicowego ekstremizmu, jaka przylgnęła do tych partii w wyniku formułowania radykalnych sądów, sprzyja często odrzucaniu en bloc ich diagnozy sytuacji w UE.

Rekapitulując, propozycje programowe wymienionych niemieckich partii w ich zdecydowanej większości oznaczałyby cofnięcie pozytywnych osiągnięć dotychczasowej integracji Europy. Ograniczanie się do myślenia w kategoriach niemieckiego interesu narodowego stanowi zapewne też rezultat niezrozumienia mechanizmów i logiki powojennych losów Starego Kontynentu, a przede wszystkim pokojowego efektu integracji. W podobnym kontekście można analizować programy polskich partii nacjonalistycznych. Ich wspólne elementy programowe, zbliżone do postulatów partii niemieckich, stanowią: antyamerykanizm, niechęć wobec biurokracji europejskiej, sprzeciw wobec koncepcji budowy jednego państwa europejskiego, krytyka procesu zrzekania się suwerenności narodowej, uniformizacja kulturowa. W programach partii niemieckich więcej uwagi poświęcono jednak antyislamizmowi oraz krytyce polityki migracyjnej rządu Niemiec. W myśli polskiego nacjonalizmu skupiano się częściej na rodzimych problemach narodowych. Wszystkie one, zarówno w przypadku partii polskich, jak i niemieckich, rozpatrywane byly w kontekście idei narodowej i państwa narodowego, jako najważniejszych w myśli nacjonalistycznej.

\section{Bibliografía}

30 Schwerpunkte zu den Wahlen 2014. Sonderveröffentlichung zu den Wahlen im Jahr 2014. Standpunkte und Kandidaten der Republikaner, http://rep.de/upload/CMS/PDF/30_Punkte_EKW.pdf, 12.04.2015.

Arbeit. Familie. Vaterland. Das Parteiprogramm der Nationaldemokratischen Partei Deutschlands. http://medien.npd.de, 12.04.2015.

Asylpolitik aus dem Tollhaus, „Neue Republik” 2014, nr 5.

Bäcker R. (2011), Nietradycyjna teoria polityki, Wydawnictwo Naukowe Uniwersytetu Mikołaja Kopernika, Toruń.

Beschluss vom 18. März 2003 - 2 BvB 1/01, uchwała Federalnego Trybunału Konstytucyjnego, www.bundesverfassungsgericht.de, 12.04.2015.

Beschluss vom 19. März $2015-2$ BvB 1/13, uchwała Federalnego Trybunału Konstytucyjnego www.bundesverfassungsgericht.de, 12.04.2015. 
Brandstetter M. (2012), Die „neue” NPD: Zwischen Systemfeindschaft und bürgerlicher Fassade, Parteimonitor Aktuell, Konrad Adenauer Stiftung, Berlin.

Braun S., Geisler A., Gerster M. (2009), Die extreme Rechte. Einleitende Betrachtungen, w: Strategien der extremen Rechten. Hintergründe - Analysen - Antworten, red. S. Braun, A. Geisler, M. Gerster, VS Verlag für Sozialwissenschaften, Wiesbaden.

Bundesamt für Verfassungsschutz, www.verfassungsschutz.de/de/arbeitsfelder/af-rechtsextremismus/was-ist-rechtsextremismus, 12.04.2015.

Bürgerbewegung PRO NRW Programm beschlossen am 9. September 2007 in Bonn, geändert am 08. März 2013 in Leverkusen. 7 Punkte pro NRW, www.bundeswahlleiter.de, 12.04.2015.

Das Europa der Vaterländer, http://www.rep.de/content.aspx?ArticleID=510ed20b-a863-4855-ba15$-5 \mathrm{dfb} 271 \mathrm{af} 378,12.04 .2015$.

Deklaracja Trzeciej Pozycji, Narodowe Odrodzenie Polski, http:/www.nop.org.pl/deklaracja-trzeciej-pozycji/, 27.01.2015.

Edathy S., Sommer B. (2009), Die zwei Gesichter des Rechtsextremismus in Deutschland-Themen, Machtressourcen und Mobilisierungspotentiale der extremen Rechten, w: Strategien der extremen Rechten. Hintergründe - Analysen - Antworten, red. S. Braun, A. Geisler, M. Gerster, VS Verlag für Sozialwissenschaften, Wiesbaden.

Europa wählt rechts. Nationaldemokratisches Europawahlprogramm, https://npd.de/inhalte/daten/ dateiablage/br_201401_europaprogramm.pdf.

Für die deutsche Republik - Raus aus dieser EU!, 15.03.2009, http://www.rep.de/content.aspx?ArticleID=4217518b-a7f1-45c5-b60f-fd75cbfbcb14, 12.04.2015.

Für ein Europa der Vaterländer Europapolitische Thesen der Bürgerbewegung Pro NRW, http://pro-nrw.net, 12.04.2015.

Gmurczyk A., Kiedy Polacy pokochaja Unię..., 2.06.2014, „Dziennik Narodowo-Radykalny Nacjonalista.pl", http://www.nacjonalista.pl/2014/06/02/adam-gmurczyk-dla-nacjonalista-pl-kiedy-polacy-pokochaja-unie/, 21.01.2015.

Gmurczyk A., Nowoczesny nacjonalizm (przemówienie ideowo-programowe wygłoszone na Konferencji Europejskiego Frontu Narodowego), Narodowe Odrodzenie Polski. http://www.nop.org.pl/nowoczesny-nacjonalizm/, 27.01.2015.

Jansen F. (2013), Eine Partei in der Krise - auch ohne Verbotsantrag, „Der Tagesspiegel”, 3.12.2013.

Jansen F., Birnbaum R. (2003), NPD-Verbot in Kahrlsruhe gescheitert, „Der Tagesspiegel”. 19.03.2003.

Kailitz S. (2009), Die Deutsche Volksunion und die Republikaner: Vergleichende Betrachtungen zur Entwicklung und zum ideologischen Profil, w: Strategien der extremen Rechten. Hintergründe - Analysen - Antworten, red. S. Braun, A. Geisler, M. Gerster, VS Verlag für Sozialwissenschaften, Wiesbaden.

Kuczur T. (2008), Ethnos i polities. Naród a spoleczeństwo obywatelskie we wspótczesnej Europie, Wydawnictwo Adam Marszałek, Toruń.

Maćkowiak P. (1983), Narodowo-Demokratyczna Partia Niemiec. Wizerunek partii neofaszystowskiej, Wydawnictwo Prawnicze, Warszawa.

Maj Cz., Maj E. (2007), Narodowe ugrupowania polityczne w Polsce 1989-2001, Wydawnictwo Uniwersytetu Marii Curie-Skłodowskiej, Lublin.

Maj E. (2008), Myśl narodowa i nacjonalistyczna, w: Myśl polityczna w Polsce po 1989 roku. Wybrane nurty ideowe, red. E. Maj, A. Wójcik, Wydawnictwo Uniwersytetu Marii $\mathrm{Cu}-$ rie-Skłodowskiej, Lublin.

Mudde C. (2000), The ideology of the extreme right, Manchester University Press, Manchester. 
Musimy walczyć razem przeciw wspólnym wrogom - Frank Franz, nowy przewodniczacy NPD, w wywiadzie dla „Nacjonalista.pl”, 14.11.2014, http:/www.nacjonalista.pl/2014/11/14/musimy-walczyc-razem-przeciw-wspolnym-wrogom-frank-franz-nowy-przewodniczacy-npd-w-wywiadzie-dla-nacjonalista-pl/, 21.01.2015.

Negocjacje z NPD zwieńczone sukcesem. „Mamy sojusz”, 1.04.2013, „Dziennik Narodowo-Radykalny Nacjonalista.pl", http://www.nacjonalista.p1/2013/04/01/negocjacje-z-npd-zakonczone-sukcesem-mamy-sojusz/, 21.01.2015.

Neugebauer G. (2001), Extremismus - Rechtsextremismus - Linksextremismus. Einige Anmerkungen zu Begriffen, Forschungskonzepten, Forschungsfragen und Forschungsergebnissen, w: Rechtsextremismus in der Bundesrepublik Deutschland. Eine Bilanz, red. W. Schubarth, R. Stöss, Leske + Budrich, Opladen.

Niemieccy nacjonaliści przeciw inwazji na Syrię, 6.09.2013, „Dziennik Narodowo-Radykalny Nacjonalista.pl", http://www.nacjonalista.pl/2013/09/06/niemieccy-nacjonalisci-przeciw-inwazji-na-syrie/, 21.01.2015.

Pfahl-Traughber A. (2009), Die , alte” und die ,neue” NPD. Eine vergleichende Betrachtung zu Gefahrenpotential und Profil, w: Rechtsextremismus in der Bundesrepublik Deutschland. Eine Bilanz, red. W. Schubarth, R. Stöss, Leske + Budrich, Opladen.

Programm der Partei DIE RECHTE, http:/worch.info/die-rechte/pdf/Parteiprogramm.pdf, 12.04.2015.

Reißmann O. (2011), Fusion mit DVU: NPD schmiedet Pakt der Rechtsextremen, „Spiegel Online”, 15.01.2011.

Rommelspacher B. (2002), Anerkennung und Ausgrenzung. Deutschland als multikulturelle Gesellschaft, Campus Verlag, Frankfurt am Main.

Salafisten und Dschihadisten auf dem Vormarsch (2014), „Neue Republik”, nr 5.

Sozial, patriotisch, äkologisch. Bundesparteiprogramm. Die Republikaner (2002), http:/www.rep.de/ upload/REP_Daten/Werbemittel/_Allgemein/Parteiprogramm/BUND_parteiprogramm_2011.pdf, 12.04.2015.

Speit A. (2014), „Die Rechte” und EU-Wahl. Zu weniger Anhänger, www.taz.de, 4.03.2014.

Staud T. (2006), Moderne Nazis. Die neuen Rechten und der Aufstieg der NPD, Kiepenheuer \& Witsch, Köln.

Sterlingow M., Wąs M. (2006), Herbatka z nazista, „Gazeta Wyborcza”, „Duży Format” z dnia $23.10 .2006 \mathrm{r}$.

Tejkowski B., Miejsce i rola stowiańskiej Polski w epoce inwazji globalizmu (referat na międzynarodową konferencję „Polska, Czechy, Słowacja, Serbowie Łużyccy - możliwości i perspektywy współpracy i rozwoju"), 30.11.2002-1.12.2002, Polska Wspólnota Narodowa, http://www.pwn.waw.pl, 4.02.2009.

Tejkowski B., Wspólnota Slowiańska historyczna szansa rozwoju Państw Slowiańskich i wspótpracy euroazjatyckiej (referat na VIII Zjazd Wszechsłowiański), 2-5.04.2001, http://www.pwn.waw.pl, 30.01.2007.

Tejkowski B., Zwycięstwo nad faszyzmem przestaniem jedności stowiańskiej (referat na IX Światowy Sobór Narodu Rosyjskiego „Jedność Narodów, solidarność ludzi, zwycięstwo nad faszyzmem i terroryzmem"), 9-10.03.2005, Polska Wspólnota Narodowa, http://www.pwn.waw.pl, 4.02.2009.

UE trzeba zniszczyć, a nie reformować-stanowisko w sprawie eurowyborów, 18.05.2014, „Dziennik Narodowo-Radykalny Nacjonalista.pl", http://www.nacjonalista.pl/2014/05/20/ue-trzeba-zniszczyc-a-nie-reformowac-stanowisko-w-sprawie-eurowyborow/, 21.01.2015.

VonSchwarzau: Kwestia Ślaska, 13.01.2014, „Dziennik Narodowo-Radykalny Nacjonalista.pl”, http:/www.nacjonalista.pl/2014/01/13/vonschwarzau-kwestia-slaska/, 21.01.2015. 
Wittrock P., Diekmann F., Hebel C. (2012), „Die Rechte”: Neue Rechtspartei will NPD ersetzen, „Spiegel Online”, 27.07.2012.

Zasady ideowe nacjonalizmu, Narodowe Odrodzenie Polski, http://www.nop.org.pl/zasady-ideowe-nacjonalizmu/, 27.01.2015.

Zasady programowe, Narodowe Odrodzenie Polski, http://www.nop.org.pl/zasady-programowe/. 27.01.2015.

\section{Streszczenie}

Tematem artykułu jest nacjonalizm rozumiany jako kierunek myśli politycznej, w której idea narodu stanowi wartość najwyższą. Do grona głównych polskich partii nacjonalistycznych działających w ostatnim ćwieréwieczu zaliczyć można takie, jak: Narodowe Odrodzenie Polski, Polska Wspólnota Narodowa i Stronnictwo Narodowe „Szczerbiec”. Główne partie nacjonalistyczne w Niemczech to: Narodowodemokratyczna Partia Niemiec, Republikanie, Prawica, Pro NRW (Północna Nadrenia-Westfalia). Skrajnie prawicowe partie w Polsce i Niemczech negują Unię Europejską i są przeciwnikami procesu integracji europejskiej. Partie nacjonalistyczne w Europie obawiają się globalizacji gospodarczej i kulturowej, wielokulturowości, imigrantów, Islamu, konsumpcjonizmu i materializmu, które w ich opinii zagrażają egzystencji narodów.

Slowa kluczowe: Nacjonalizm, integracja europejska, Unia Europejska, imigracja

\section{The voice of Polish and German nationalists in the debate on European integration}

\section{Summary}

The subject of this paper is nationalism as a direction of political thinking, where the idea of the nation is the dominant principle. The main Polish nationalist political parties of the recent 25 years include: National Revival of Poland, Polish National Community and National Party „Szczerbiec". The main German nationalist political parties include: National Democratic Party of Germany, The Republicans, The Right, Pro NRW (North Rhine-Westphalia). Far-right parties in Poland and in Germany are against the European Union and the process of European integration. The nationalist parties in Europe fear economic and cultural globalisation, multiculturalism, immigrants, Islam, materialism and consumerism that - in their opinion - threaten their respective nations.

Key words: nationalism, European integration, European Union, immigration 